\title{
Morphological and molecular identification of Alaria paradisea (Phaeophyceae, Laminariales) from the Kurile Islands
}

\author{
Anna V. Klimova ${ }^{1}$, Nina G. Klochkova ${ }^{1}$, Tatyana A. Klochkova ${ }^{1,2}$ and Gwang Hoon Kim ${ }^{2, *}$ \\ ${ }^{1}$ Kamchatka State Technical University, Petropavlovsk-Kamchatsky 683003, Russia \\ ${ }^{2}$ Department of Biology, Kongju National University, Kongju 32588, Korea
}

\begin{abstract}
Alaria is the second largest genus of the Laminariales, which is distributed far into the northern Pacific and Atlantic oceans. Due to its high morphological plasticity, over 100 specific and sub-specific names have been used in Alaria, this has been tailored down to the present 17 species through morphological revision and molecular phylogenetic analysis. Endemic species of Alaria from Russian Far East have not been thoroughly revised since their original description, and few of them were confirmed using molecular data until recently. We carried out morphological and molecular studies on A. paradisea which is an endemic species distributed on the Kurile Islands, first described by Miyabe and Nagai in 1932 as Pleuropterum paradiseum. The range of morphological variability and its distribution was re-evaluated using the type specimen as well as other specimens. Analyses of partial mitochondrial cytochrome c oxidase subunit 1 and nuclear-encoded internal transcribed spacer sequences showed that A. paradisea nested within the genus Alaria, but differs morphologically from any other Alaria species in having additional sporophylls with a central midrib ( $\beta$-sporophylls). Our results showed that A. paradisea clearly belongs to the genus Alaria based on DNA data, although the key morphological character that was used to include this species to the genus Pleuropterum, $\beta$-sporophylls, is stable and distinguishes it from other Alaria species.
\end{abstract}

Key Words: Alaria paradisea; brown algae; endemic kelp; Kurile Islands; molecular phylogeny; morphology; Pleuropterum paradiseum

\section{INTRODUCTION}

The application of molecular-phylogenetic methods has resulted in a radical revision of traditional systematics in laminariaceaen species for last decade (Lane et al. 2006), but there is still a long list of species waiting for taxonomic re-evaluation. There are many endemic species, which were established from limited number of specimens collected in single expedition in a very remote place of far north. The first revision of the laminariacean flora in the Russian Far East was performed 43 years ago (Petrov 1975). Since then, two new genera and species,
Undariella and Tauya (Petrov and Kusakin 1997, Klochkova and Krupnova 2004), were described in this region, generic attribution of Lessonia laminarioides Postels et Ruprecht was revised using molecular methods (Cho et al. 2006), and the taxonomic entity of several endemic species and genus was confirmed (Klochkova and Klochkova 2010, Klochkova et al. 2010, 2012). Recently, molecular data on a rare endemic species Tauya basicrassa Klochkova et Krupnova were published (Klochkova et al. 2017).
(9) $\$$ This is an Open Access article distributed under the terms of the Creative Commons Attribution Non-Commercial License (http://creativecommons.org/licenses/by-nc/3.0/) which permits unrestricted non-commercial use, distribution, and reproduction in any medium, provided the original work is properly cited.
Received December 21, 2017, Accepted February 22, 2018

* Corresponding Author

E-mail: ghkim@kongju.ac.kr

Tel: +82-41-850-8504, Fax: +82-41-850-8479 


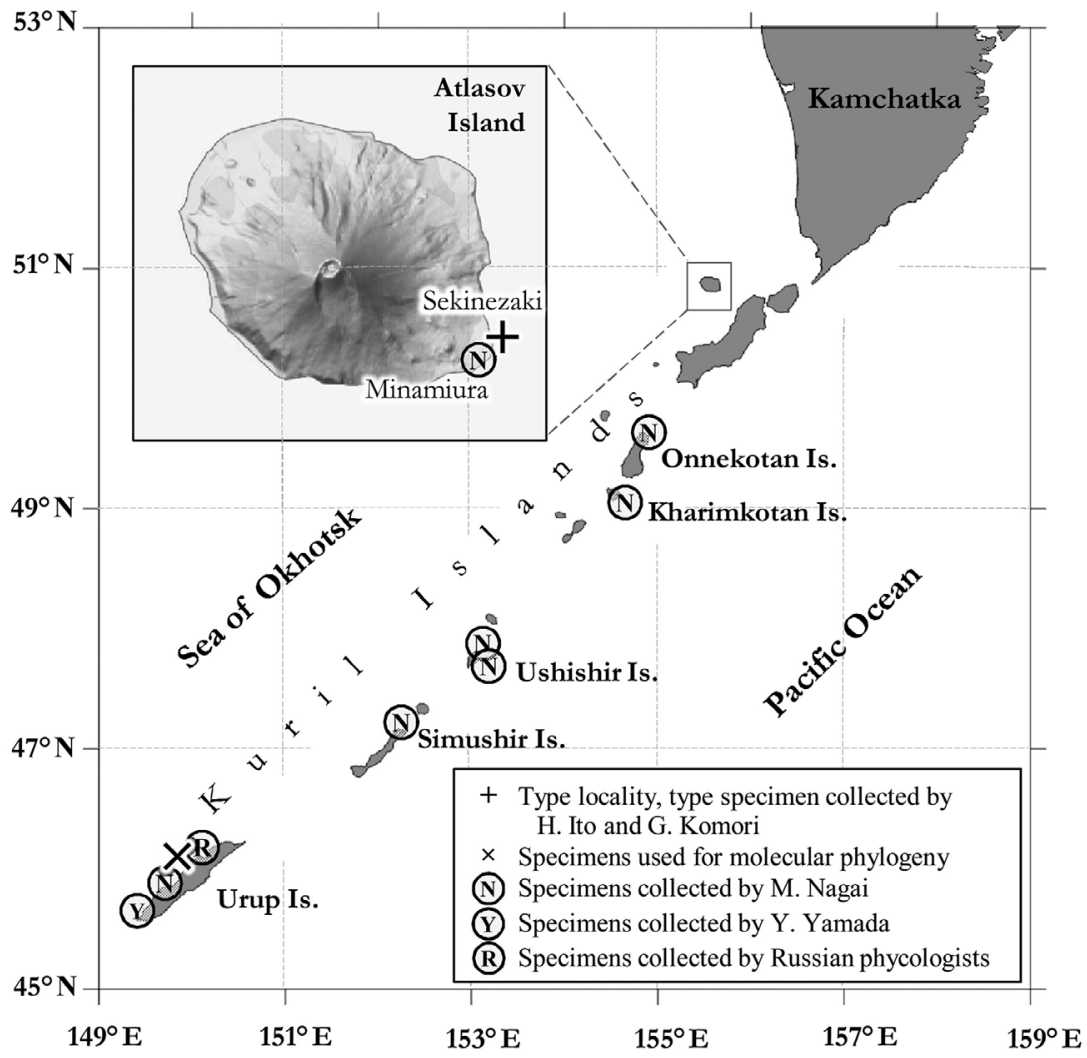

Fig. 1. Distribution of Alaria paradisea in the middle and northern Kurile Islands. Atlasov Island, the type locality of this species (inset). +, type locality; $\times$, sampling site for specimens used for DNA extraction.

The monotypic kelp genus Pleuropterum and its species, Pleuropterum paradiseum Miyabe et Nagai, were described 86 years ago from Atlasov Island, which is located on the north of the Kurile Islands chain. This taxon was originally attributed to the family Alariaceae and referred as the closest relative of Alaria, but differed from it by having heteromorphic spore-bearing blades on the rachis, with and without a central midrib (Miyabe and Nagai 1932). These spore-bearing blades with a central midrib were referred to in different ways, such as "sterile pinnae" (Miyabe and Nagai 1933, Nagai 1940), "leaves with midrib" (Yamada 1935), and "sterile side branches"(Widdowson 1971).

During studies of the marine flora from the middle and northern Kurile Islands, $P$. paradiseum was further divided into three forms: f. typicum, f. brevipes, and f. fasciculatum (Miyabe and Nagai 1933, Yamada 1935, Nagai 1940). This species was reported as rare and grew together with other Alaria spp. on a rocky substrate in the upper subtidal zone.

While revising the genus Alaria in the World Ocean, Widdowson (1971) transferred P. paradiseum to the ge- nus Alaria and proposed a new nomenclatural combination: Alaria paradisea (Miyabe et Nagai) Widdowson. As he suggested, the status of an independent genus, Pleuropterum, could not be supported by a single morphological character, i.e., spore-bearing blades with a central midrib on the rachis ( $\beta$-sporophylls). Moreover, he suggested that $\beta$-sporophylls were the result of a mutation, so that different forms of Pleuropterum were closer to certain species of Alaria than to each other (Widdowson 1964). He also abolished all previously described taxonomic forms of this species, although local taxonomists continued to refer to this species as P. paradiseum (Petrov 1975, Klochkova 1998, Ogorodnikov 2007).

Despite the high economic importance of kelp species, not all are well-studied. So far, very little is known about the endemic kelp species from the Russian Far East, including Costulariella kurilensis, Feditia simuschirensis, Phyllariella ochotensis, P. paradiseum (= A. paradisea) and Undariella kurilensis. In most cases, information about these taxa is limited to a brief diagnoses based on single sample and illustrations from low-quality black and white drawings, such as in the case of A. paradisea. 
In this paper, we present the first molecular-phylogenetic analysis of $P$. paradiseum based on the mitochondrial cytochrome c oxidase subunit 1 (COI) and nuclearencoded internal transcribed spacer (ITS) sequences using recently collected specimens from the Kurile Islands. The morphological characteristics of this species were re-evaluated based on type specimen as well as other specimens.

\section{MATERIALS AND METHODS}

\section{Sample collection and specimen observation}

Samples of A. paradisea were collected by A. V. Klimova on Aug 16, 2015 during the Kurile-Commander expedition held by Elyakov's Pacific Institute of Bioorganic Chemistry onboard the research vessel "Academician Oparin." During this expedition, she collected four adult plants from the Sea of Okhotsk side of Urup Island $\left(45^{\circ} 51^{\prime} 03^{\prime \prime}\right.$ $\mathrm{N}, 149^{\circ} 46^{\prime} 01^{\prime \prime} \mathrm{E}$ ), which is an uninhabited volcanic island (Fig. 1). The plants were found on the seashore at a distance from each other, growing together with other Alaria spp. attached to rocky substrate. We used these samples in anatomical studies and to extract DNA. These plants are currently stored in Kamchatka State Technical University (KamchatGTU) as herbarium sheets and in Kongju National University (KNU) as voucher samples for DNA (specimen vouchers: Alpar_Urup01, Alpar_Urup02, Alpar_Urup03, Alpar_Urup8199). In addition, we studied herbarium collections by Japanese phycologists stored in the Natural History Museum of Hokkaido University (herbarium code: SAP), including the type and other specimens of A. paradisea and also specimens collected during phycological surveys conducted by researchers from the Institute of Fisheries and Oceanography (SakhNIRO) near Sakhalin Island and Kurile Islands, which are currently stored in the herbarium of the Komarov's Botanical Institute (herbarium code: LE) and KamchatGTU (Table 1). To study the anatomy of plants, we made cross sections (6-10 $\mu \mathrm{m}$ thick) in different parts of the thallus using a Starlet 2212 Cryostat microtome (Bright, UK) and examined them using an Olympus BX53 microscope equipped with Olympus DP73 camera (Olympus, Japan).

\section{Molecular identification and phylogenetic anal- ysis}

For extraction of genomic DNA, pieces of algal thalli were rehydrated in sterilized seawater and their surface was thoroughly cleaned with a fine brush. They were transferred to $2.0 \mathrm{~mL}$ cryotubes and frozen in liquid nitrogen. The cryotubes were then shaken at 5,000 rev min ${ }^{-1}$ for 2 min with a cell homogenization machine. The DNA was then extracted using an Invisorb Spin Plant Mini Kit (Invitek, Berlin-Buch, Germany) with some modifications of the manufacturer's protocol that we applied in case of extracting DNA from the kelp samples (i.e., longer incubation time in $65^{\circ} \mathrm{C}$ and on ice, depending on viscosity of samples). The nuclear-encoded ITS was amplified with the primer sets LB1-BC2 (ITS1 region) and YB1-LB2 (ITS2 region) (Saunders and Druehl 1993), and partial mitochondrial COI gene was amplified using the primer set GazF2-GazR2 (Yoon and Boo 1999, Lane et al. 2006, 2007). TaKaRa Ex Taq polymerase (Takara Biomedicals, Otsu, Japan) was used for the polymerase chain reaction

Table 1. Specimens of Alaria paradisea preserved in the Natural History Museum of Hokkaido University (SAP), the Komarov's Botanical Institute (LE), and the Kamchatka State Technical University (KamchatGTU)

\begin{tabular}{|c|c|c|c|c|c|}
\hline Species name (basionym) & Collection site & Collection date & Collector & $\begin{array}{l}\text { Place of specimen's } \\
\text { storage }\end{array}$ & Reference \\
\hline $\begin{array}{l}\text { Pleuropterum paradiseum } \\
\text { f. typicum (type specimen) }\end{array}$ & Atlasov Island & Aug 10, 1926 & H. Ito, G. Komori & SAP & $\begin{array}{l}\text { Miyabe and Nagai } \\
\text { (1932) }\end{array}$ \\
\hline P. paradiseum $\mathrm{f}$. typicum & Atlasov Island & Aug 1, 1930 & M. Nagai & SAP & $\begin{array}{l}\text { Miyabe and Nagai } \\
\text { (1932) }\end{array}$ \\
\hline P. paradiseum $\mathrm{f}$. brevipes & Simushir Island & Jul 22, 1930 & M. Nagai & SAP & Nagai (1940) \\
\hline P. paradiseum $\mathrm{f}$. fasciculatum & Urup Island & Aug 1933 & Y. Yamada & SAP & Yamada (1935) \\
\hline \multirow[t]{3}{*}{ P. paradiseum f. typicum } & Ushishir Island & Aug 12, 1935 & M. Nagai & SAP & Nagai (1940) \\
\hline & Ushishir Island & Aug 15, 1935 & M. Nagai & SAP & Nagai (1940) \\
\hline & Onekotan Island & Aug 15, 1935 & M. Nagai & SAP & Nagai (1940) \\
\hline P. paradiseum (3 specimens) & Urup Island & Aug 2-5, 1967 & Unknown & LE & Petrov (1975) \\
\hline P. paradiseum & Urup Island & Jul 4, 1971 & I. Gussarova & KamchatGTU & This study \\
\hline P. paradiseum (4 specimens) ${ }^{\mathrm{a}}$ & Urup Island & Aug 16, 2015 & A. Klimova & KamchatGTU & This study \\
\hline
\end{tabular}

ased for DNA analysis. 
(PCR) amplifications. The following PCR program was used: initial denaturation at $95^{\circ} \mathrm{C}$ for $4 \mathrm{~min}$, followed by 35 cycles of denaturation at $94^{\circ} \mathrm{C}$ for $30 \mathrm{~s}$, annealing at $55^{\circ} \mathrm{C}$ for $30 \mathrm{~s}$, extension at $72^{\circ} \mathrm{C}$ for $1.5 \mathrm{~min}$ and a final extension at $72^{\circ} \mathrm{C}$ for $10 \mathrm{~min}$. PCR products were checked on 1.2\% agarose gel (Agarose LE Analytical, NobleChem, Molecular Grade, NobleBio, Suwon, Korea) for length, concentration, and purity. Sanger sequencing was performed commercially (Cosmogenetech Co. Ltd., Seoul, Korea). In total, we sequenced 879 bp of two internal transcribed spacers (ITS1 and ITS2) of the nuclear-encoded rRNA cistron, hereafter referred to as ITS; the alignment was trimmed to $771 \mathrm{bp}$-long to match the length of other sequences downloaded from the NCBI, and it included 87 gaps. For COI gene, the alignment was 669 bp-long without any gaps.

Our new sequences and sequences from GenBank (NCBI 2018) were aligned using Geneious (ver. 10.2.3, Biomatters, Auckland, New Zealand) and the alignments were refined by eye. The trees were generated using Bayesian phylogenetic analysis (MrBayes 3.2.2) (Huelsenbeck and Ronquist 2001) using a general time reversible (GTR) substitution model, 3,000,000 generations, sub-sampled every 1,000 generations and a burn-in length of 300,000 generations. Maximum likelihood analysis used RAxML 8.2.11 (Stamatakis 2014) using a GTR + gamma model. Bootstrap support values (\%) were calculated based on 1,000 bootstrap replicates. Our new sequences have been deposited in GenBank under the following accession numbers: MG913352-MG913355 (COI) and MG913356MG913359 (ITS).

\section{RESULTS}

\section{History of type and other authentic specimens}

The type locality of Alaria paradisea is Atlasov Island, which is the most northern island of the Greater Kurile Ridge. The first specimens of this species were collected by Ito and Komori in 1926 from Cape Lava (Japan, Sekinezaki), which is located in the southeastern part of Atlasov Island (Figs 1, 2A \& B). In 1930, M. Nagai collected this species in Troika Bay (Japan, Minamiura) on Atlasov Island (Fig. 2C \& D). Specimens from Cape Lava were used to describe the genus Pleuropterum and its species, P. paradiseum (Fig. 2A \& B), but they were not labeled as type. Specimens from Troika Bay were labelled as "cotype" by M. Nagai (Fig. 2C \& D) (Miyabe and Nagai 1932). Widdowson (1971) designated specimen from Cape Lava as lectotype of A. paradisea (Fig. 2A \& B).

Yamada (1935) described another species of Pleuropterum and P. fasciculatum from the southern part of Urup Island. This specimen, which was stored in the Natural History Museum of Hokkaido University (SAP) until 2015 is shown in Fig. 2E \& F. Later, when describing the marine seaweed flora of the Kurile Islands, Nagai (1940) listed only one species of Pleuropterum, but distinguished its three forms: f. typicum, f. brevipes, and f. fasciculatum, thus lowering the taxonomic status of Yamada's species to a form.

It should be noted that we observed these specimens in SAP in July 2010 and July 2015, but they were not present in SAP in December 2017, since this part of collection was loaned to the University of Tokyo for verification of samples after renovation of SAP (Tsuyoshi Abe personal communication). The samples did not have acronyms during the time we observed them.

\section{Sampling localities and characteristics of speci- mens in this study}

Several other specimens have been collected from the northern and middle Kurile Islands (Yamada 1935, Nagai 1940, Petrov 1975) (Table 1, Fig. 1). It is noteworthy that 7 specimens were collected over 80 years ago and four specimens over 40 years ago. All of them, except specimens illustrated in Fig. 2, are in poor condition. Some plants were dried in pieces that cannot be correlated with each other, especially specimens from LE collection in Saint-Petersburg. These old samples could not be used in the anatomical and molecular-phylogenetic studies because of the general degradation. Thus, we used fresh material collected in 2015 from Urup Island to illustrate the internal structure and for DNA extraction.

\section{Morphology}

Alaria paradisea has two types of sporophylls: without midrib and those with a central midrib. The latter can develop sporangial sori, similar to ordinary sporophylls, so they perform reproductive function. Therefore, we call sporophylls without midrib as $\alpha$-sporophylls and sporophylls with a central midrib as $\beta$-sporophylls, following terminology by Gollerbah (1977) used for higher plants with different types of leaves ( $\alpha$ - and $\beta$-leaves, respectively).

The forms of A. paradisea (Fig. 2A \& E) differ significantly by thalli sizes, including stipe, main blade and $\alpha$-sporophylls (Table 2). Some characteristics overlap in 

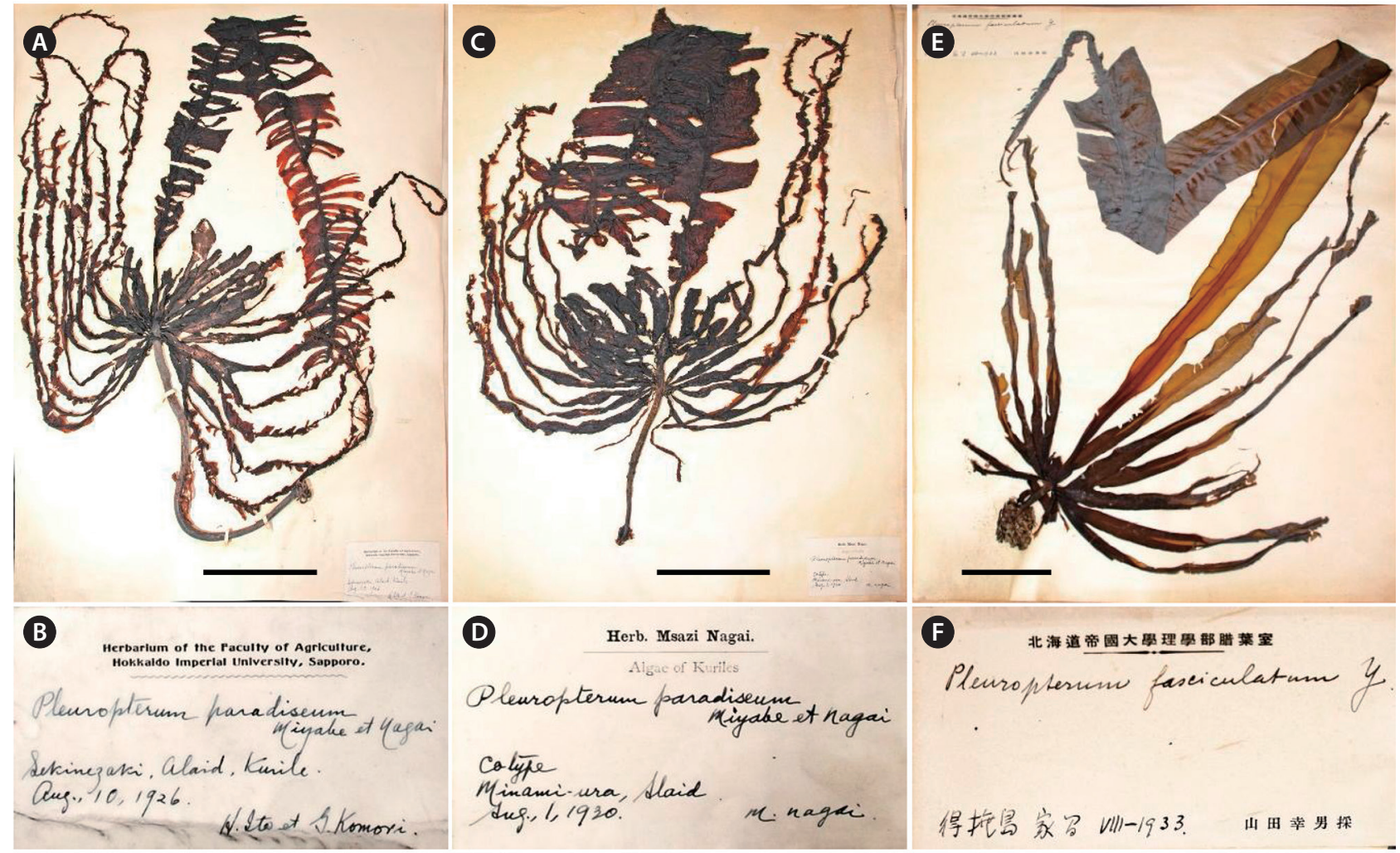

G

$\boldsymbol{\Theta}$
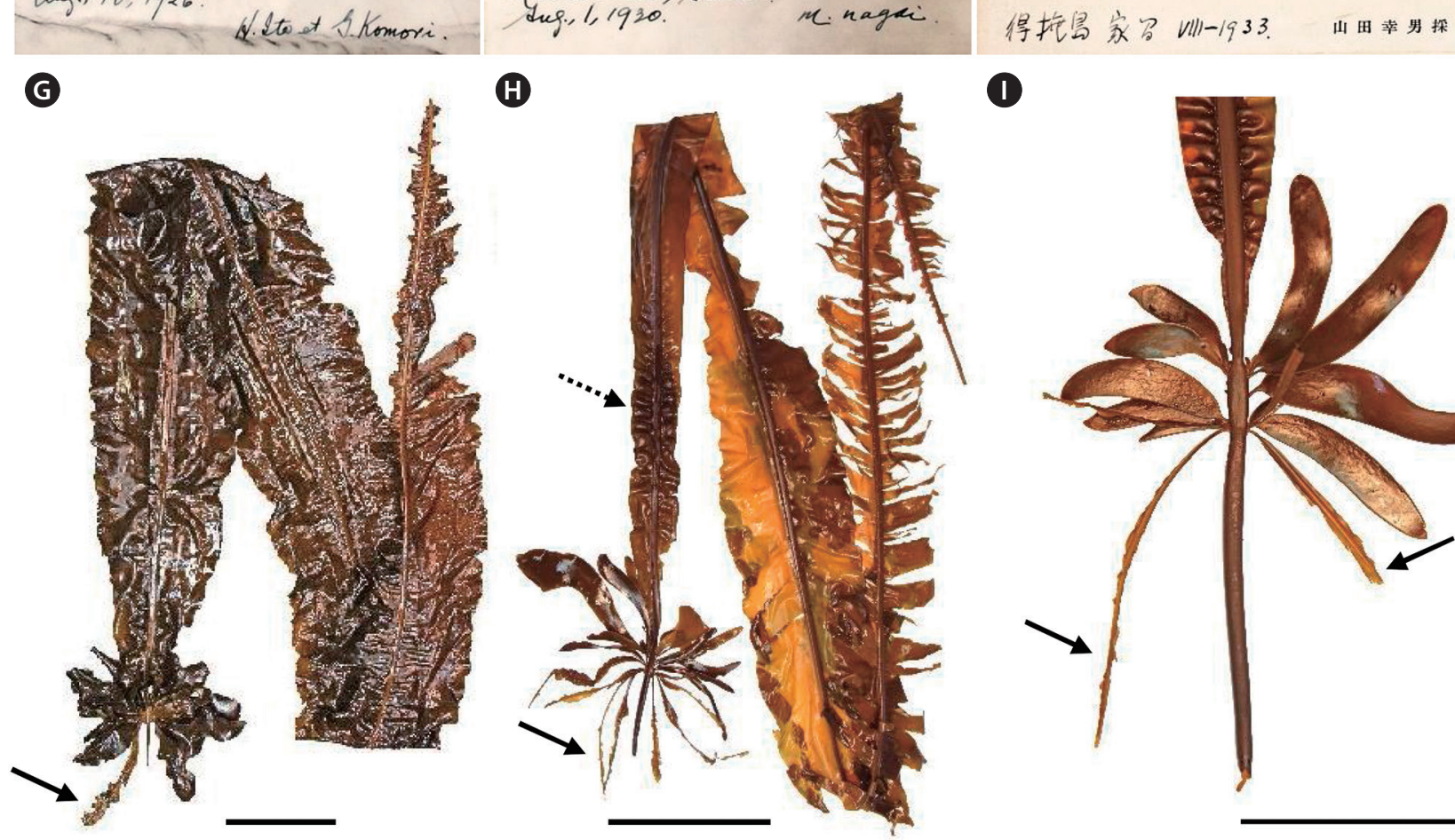

(1)

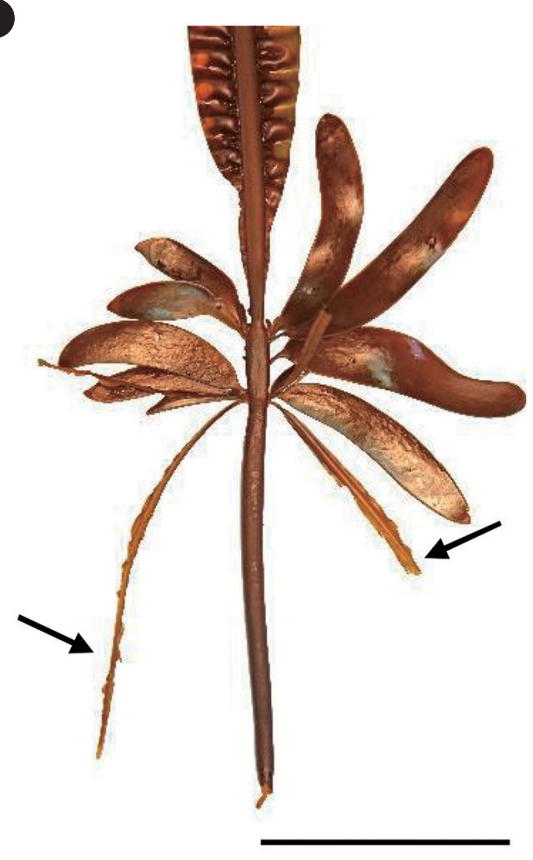

Fig. 2. Type and other specimen of Alaria paradisea (A-F) and fresh plants collected from Urup Island in 2015 (G-I). (A \& B) Lectotype collected on Aug 10, 1926 by H. Ito and S. Kumori from Sekinezaki (Atlasov Island). (C \& D). Specimen collected on Aug 1, 1930 by M. Nagai from Minamiura on Atlasov Island and labelled as "Co-type" by M. Nagai. (E \& F) Specimen collected in August 1933 from Urup Island (labelled as P. paradiseum f. fasciculatum). (B, D \& F) Closeup of label. (G-I) In newly collected plants, $\beta$-sporophylls with midrib were not numerous (solid arrows). In some plants, sporangial sori developed on the main blade $(\mathrm{H}$, dashed arrow). Scale bars represent: $A, C, E \& I, 10 \mathrm{~cm} ; G \& H, 20 \mathrm{~cm}$. 
all forms, which makes infra-species subdivision more difficult. For example, A. paradisea f. typicum (Fig. 2A \& C) has very long holdfast $(40-60 \mathrm{~cm})$ and small blade (80$135 \mathrm{~cm}$ ), thus it can be easily distinguished from f. brevipes and f. fasciculatum (Fig. 2E), which in turn differ from each other in the location of $\alpha$ - and $\beta$-sporophylls on the rachis of plants.

Our samples of A. paradisea from Urup Island cannot easily be attributed to any form of this species (Fig. 2GI). The stipe length is longer than $15.8 \mathrm{~cm}$, which is similar to that in f. typicum. The sizes of the rachis and blade and also the location of $\alpha$ - and $\beta$-sporophylls are closer to f. fasciculatum (Table 2). Our samples from Urup Island have fewer number of $\beta$-sporophylls, from 1 to 9 . The surface of mature $\alpha$-sporophylls was entirely covered with sporangial sori, so that the sterile border was narrow or absent. In some plants, sori developed not only on $\alpha$-sporophylls, but also in the basal part of the main blade (Fig. 2H, dashed arrow). In old herbarium specimen collected by I. Gussarova on Jul 4, 1971 (Table 1) sporangial sori developed on $\beta$-sporophylls. Comparative analysis of plant dimensions in the specimens from Urup Island collected by Russian and Japanese phycologists also showed high variability of morphological characters (Table 2).

\section{Anatomy}

$\beta$-Sporophylls are sterile or bearing sporangial sori, up to $145 \mu \mathrm{m}$ thick in the lamellar part and $1.1 \mathrm{~mm}$ thick in the midrib region, covered with elongated-polygonal epidermal cells of 3.7-12.5 $\times 2.5-7.5 \mu \mathrm{m}$ in size (Fig. 3A). The meristoderm consists of 2-3 layers of dark-brown cells and is permeated with numerous mucilaginous ducts of 12-30 $\mu \mathrm{m}$ in diameter. Cortical cells below the meristoderm are densely packed. The medulla is distinguishable only in the midrib, looking like single branched hyphaelike filaments, but is absent or makes less than $5 \%$ from the total thickness in the lamellar part of $\beta$-sporophylls (Fig. 3B).

The main blade is $\geq 300 \mu \mathrm{m}$ thick in the adult plants, covered by rounded polygonal epidermal cells of 3.4-8.5 $\mu \mathrm{m}$ in diameter (Fig. 3C). The meristoderm consists of 2-3 layers of dark-colored cells. In transverse section, cortex cells are tightly packed, well-seen only in the midrib (Fig. $3 \mathrm{D})$. The pronounced medullar is composed of hyphaelike filaments, occupying most of the internal volume in the main blade.

$\alpha$-Sporophylls are formed by densely packed cells. The meristoderm is 2-3 cell-layers thick (Fig. 3E), cortex consists of 6 or more layers of cells; the medulla is welldeveloped, making up to $30-45 \%$ of the total thickness of $\alpha$-sporophylls. The thickness of mature sporangia-bearing tissue is $125 \mu \mathrm{m}$ on average, rarely reaching $150 \mu \mathrm{m}$. Unicellular paraphyses are 100-130 $\mu \mathrm{m}$ in length; sporangia are 67-75 $\mu \mathrm{m}$ in length. Mucous caps on the top of paraphyses do not exceed $20 \mu \mathrm{m}$ in height and their width is always larger than their length.

The anatomy of stipe is typical for laminariacean al-

Table 2. Size characteristics ( $\mathrm{cm}$ ) of different forms of Pleuropterum paradiseum and other specimens from Urup Island used in this study

\begin{tabular}{|c|c|c|c|c|c|c|}
\hline Part of thallus & $\begin{array}{c}\text { Dimensions / } \\
\text { Characteristics (cm) }\end{array}$ & P. paradiseum ${ }^{\mathrm{a}}$ & P. paradiseum & $\begin{array}{l}\text { P. paradiseum } \\
\text { f. typicum }\end{array}$ & $\begin{array}{l}\text { P. paradiseum } \\
\text { f. brevipes }\end{array}$ & $\begin{array}{l}\text { P. paradiseum } \\
\text { f. fasciculatum }\end{array}$ \\
\hline \multirow[t]{2}{*}{ Stipe } & Length & $>15.8$ & $3.3-11.7$ & $40-60$ & $<15$ & $2.5-4$ \\
\hline & Width & $0.8-1$ & $0.5-0.9$ & $0.7-1.1$ & $0.4-0.9$ & $0.8-1.0$ \\
\hline Rachis & Length & $3.2-4.5$ & 2.7-3.6 & 3-9 & $2-3$ & - \\
\hline \multirow[t]{3}{*}{ Main blade } & Length & $165.8-380$ & $151.7-255.6$ & 80-135 & $300-370$ & $>300$ \\
\hline & Width & 8.7-27.5 & $15-25.2$ & 7-15 & 15-17.5 & $6.5-19$ \\
\hline & Midrib's width & $0.8-1.5$ & $1.1-1.3$ & $0.4-0.5$ & $0.6-1.4$ & $1.0-1.2$ \\
\hline \multirow[t]{5}{*}{ Sporophylls } & Number (total, $\alpha+\beta$ ) & $14-22$ & $>14$ & $32-72$ & $32-36$ & $20-30$ \\
\hline & Length $(\alpha)$ & $5.2-28.5$ & $9.4-26.1$ & 8-14 & $9-22$ & $7-12$ \\
\hline & Width $(\alpha)$ & $0.9-6$ & $1.7-6.1$ & $0.7-1.5$ & $1.2-2.1$ & $1.2-2.2$ \\
\hline & Length $(\beta)$ & $7.9-25$ & $43.2-54.9$ & $20-90$ & $35-42$ & $15-50$ \\
\hline & Width $(\beta)$ & $0.6-3.5$ & $2.7-5.4$ & $1.5-3$ & $1.0-1.2$ & $1.3-2.8$ \\
\hline $\begin{array}{l}\text { Specimen's } \\
\text { storage }\end{array}$ & - & $\begin{array}{l}\text { Urup Island; } \\
\text { KamchatGTU }\end{array}$ & Urup Island; LE & SAP & SAP & SAP \\
\hline Reference & - & This study & $\begin{array}{c}\text { Miyabe and Nagai } \\
\text { (1933), Yamada } \\
\text { (1935) }\end{array}$ & $\begin{array}{c}\text { Miyabe and Nagai } \\
\text { (1933), Yamada } \\
\text { (1935) }\end{array}$ & $\begin{array}{c}\text { Miyabe and Nagai } \\
\text { (1933), Yamada } \\
\text { (1935) }\end{array}$ & $\begin{array}{c}\text { Miyabe and Naga } \\
\text { (1933), Yamada } \\
\text { (1935) }\end{array}$ \\
\hline
\end{tabular}

KamchatGTU, the Kamchatka State Technical University; LE, the Komarov's Botanical Institute; SAP, the Natural History Museum of Hokkaido University.

a Used for DNA analysis. 


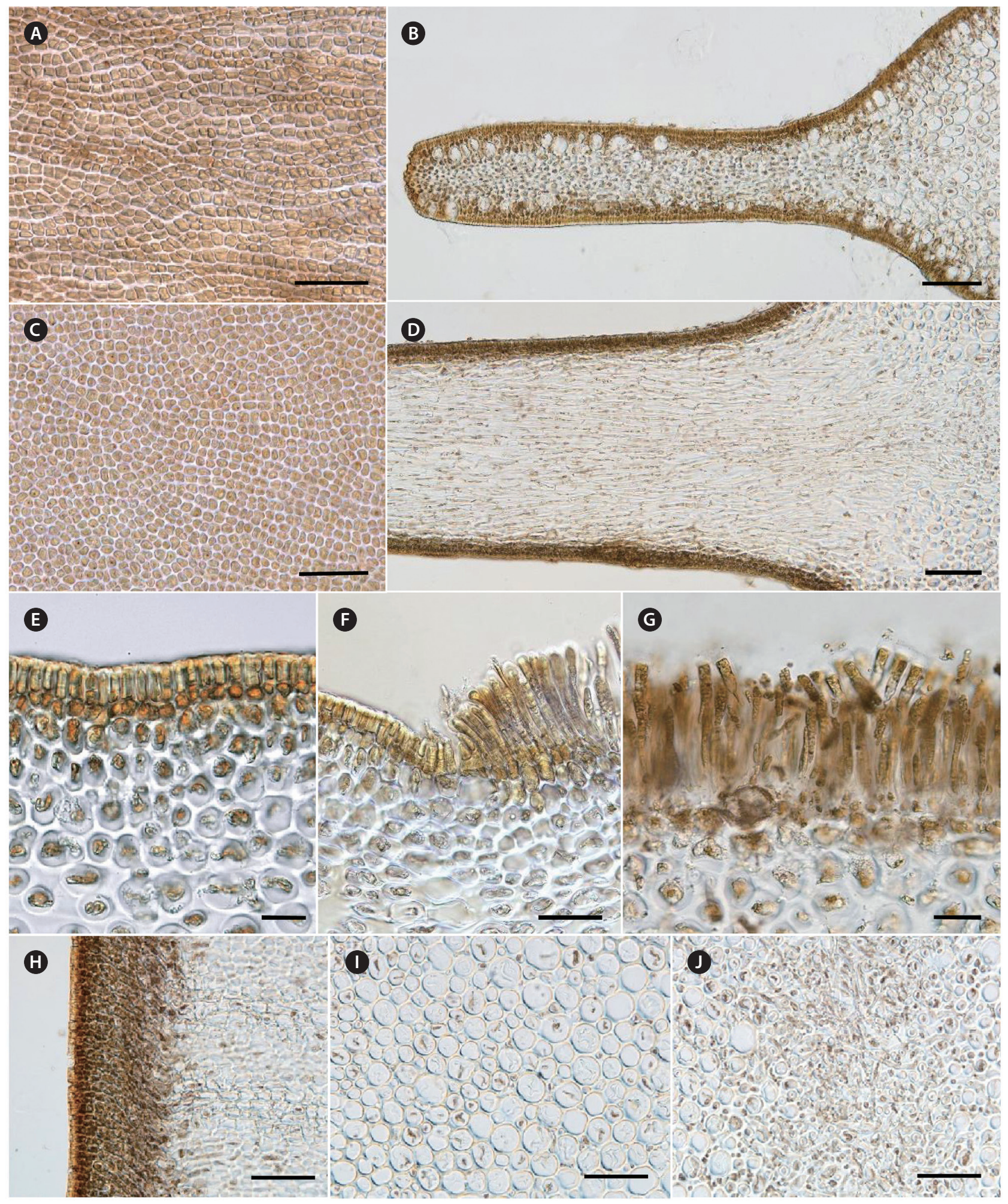

Fig. 3. Anatomy of Alaria paradisea. Plants from Urup Island collected in 2015. (A \& B) $\beta$-Sporophylls. (A) Elongated-polygonal epidermal cells observed in surface view of the $\beta$-sporophyll. (B) Numerous mucilage ducts are seen on the cross-section, midrib on the right. (C \& D) Main blade. Polygonal epidermal cells observed in surface view. (D) In the midrib region, cortex is densely packed. (E-G) a-Sporophylls in cross-section. (E) Meristoderm is 2-3 cell-layers thick. (F) Region of transition from sterile tissue to sporangial sori. (G) Sporangia and unicellular paraphyses. (HJ) Holdfast in cross-section. (H) Meristoderm is 8-9 cell-layers thick. (I) Inner cortex. (J) Medullar composed of hyphae-like filaments. Scale bars represent: A, C, F\& G, $40 \mu \mathrm{m} ; \mathrm{B}, \mathrm{D} \& \mathrm{H}-\mathrm{J}, 100 \mu \mathrm{m} ; \mathrm{E}, 20 \mu \mathrm{m}$. 


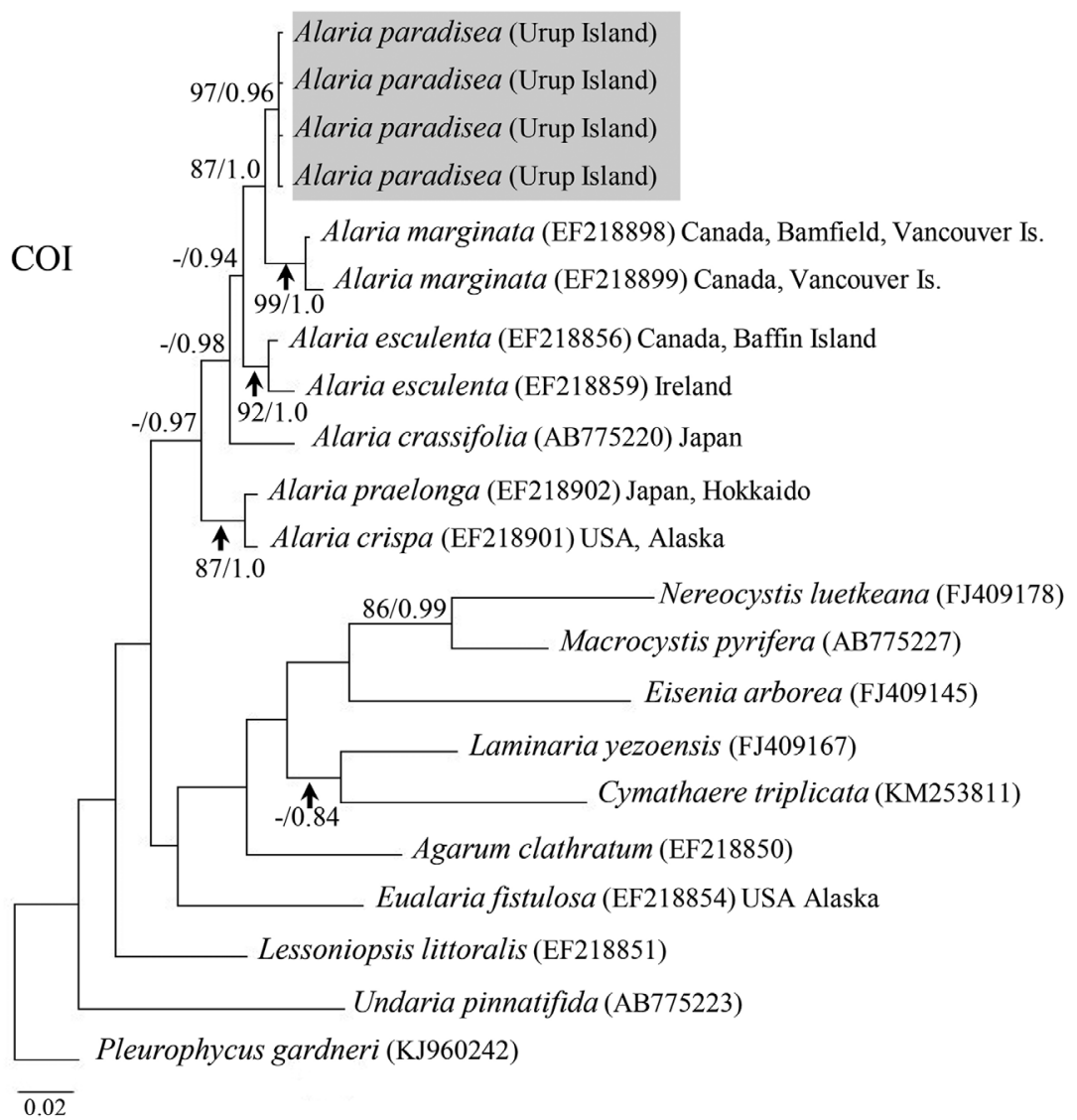

Fig. 4. Bayesian inference of phylogenies of the brown algae belonging to kelp species based on cytochrome c oxidase subunit 1 (COI) sequences. Labels on branches are posterior probabilities $(>75)$ and consensus support values (in case of posterior probability below 75 , it is marked as dash "-"). Our new sequences are highlighted with grey color.

gae. The meristoderm, inner and outer cortex and medullar are very distinct. Meristoderm consists of 8-9 layers of brown cells; its total thickness reaches $210 \mu \mathrm{m}$ (Fig. $3 \mathrm{H})$. Mucilaginous ducts were not found. The outer cortex is $500-600 \mu \mathrm{m}$ thick, consists of $15-20$ layers of cells (Fig. 3H). The inner cortex occupies most of the stipe diameter, up to $70 \%$ (Fig. 3I). The medulla is composed of a compact bundle of fine filaments, 3.6-10 $\mu \mathrm{m}$ in width (Fig. 3J).

\section{Molecular-phylogenetic analysis}

All four A. paradisea plants collected from Urup Island in 2015 had 100\% identity among themselves in COI and ITS gene sequences. Their sequences were novel and had no exact match to any registered sequence in GenBank. They showed most affinity with representatives of the genus Alaria (96.6-98.4\% sequence identity for COI and $95.2-98.4 \%$ for ITS). On both trees (Figs $4 \& 5$ ), our samples formed a separate stable clade within the genus
Alaria. In the COI phylogeny A. marginata from Pacific Canada was sister to A. paradisea. For ITS, the phylogenetic relationships were mostly not supported, but also indicated that A. paradisea was distinct from other Alaria species.

\section{DISCUSSION}

Due to its high morphological plasticity, the genus Alaria has been one of the most controversial taxa in the Laminariales. Most species are distributed far into the northern Pacific and Atlantic oceans including Russian Far East, and some species have been established through a single expedition in a very remote place where no man dwells. The information about these species is limited to a brief diagnoses and illustrations based on single sample. Widdowson (1971) revised the genus Alaria based on morphological characters and amalgamated many species and related genera including Pleurop- 


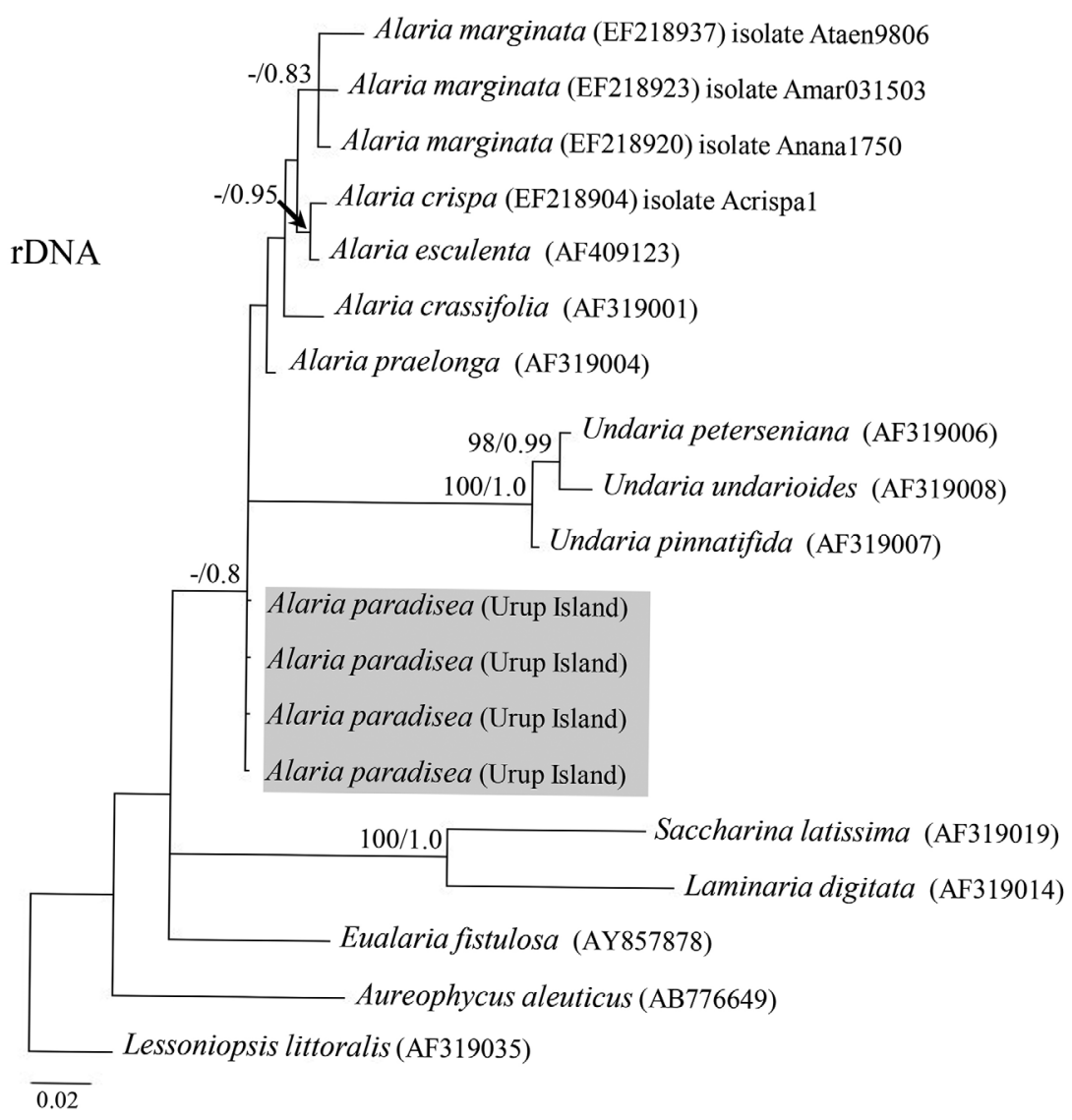

Fig. 5. Bayesian inference of phylogenies of the brown algae belonging to kelp species based on internal transcribed spacer sequences. Labels on branches are posterior probabilities $(>75)$ and consensus support values (in case of posterior probability below 75 , it is marked as dash "-"). Our new sequences are highlighted with grey color.

terum. He transferred P. paradiseum to the genus Alaria based on the assumption that $\beta$-sporophylls were the result of a mutation, which occurred in a limited number of samples and hence was not good enough for a morphological character to support the genus Pleuropterum. Although our morphological analysis using many samples collected by different researchers strongly supported that $\beta$-sporophylls are stable character distinguishing Alaria paradisea from all other species of Alaria, the character was not good enough to separate the genus. Our molecular phylogenetic analysis supported Widdowson's (1971) nomenclatural combination showing Alaria paradisea within the genus Alaria.

Obvious morphological and anatomical differences were often accompanied by equally obvious phylogenetic differences, as for example, in the genera Alaria and Eualaria (Lane et al. 2007). The anatomical difference in the central midrib has been regarded as a single most important morphological character distinguishing the genus Alaria from Eualaria, which show general resem- blance in morphology. In Eualaria, the compartments in central midrib are filled with air and enable the blades floating on the seawater surface easier than Alaria species, which have simple midrib. Traditional morphological / anatomical character of the taxon contradicts with evolutionary relationships in A. paradisea. Such cases are not rare in the systematics of kelp. The application of molecular-phylogenetic methods in this algal group has resulted in a radical revision of traditional systematics of its genera. For example, the split of Laminaria by molecular markers is different from the traditional morphological-anatomical taxonomic approach (Lane et al. 2006). Moreover, Kjellmaniella gyrata and Cymathaera japonica were included in the genus Saccharina, which made the morphological characters underlying division of the genera Kjellmaniella, Cymathaera, and Saccharina obsolete (Lane et al. 2006). Another kelp species, Lessonia laminarioides was described as a new genus and species, Pseudolessonia laminarioides (Cho et al. 2006), thus devaluing morphological characters (e.g., meristem split- 
ting) underlying separation of the families Lessoniaceae and Laminariaceae.

When determining the placement of A. paradisea, we followed the molecular-phylogenetic approach. Our molecular data showed that A. paradisea is significantly different from all other species of Alaria sequenced to date, but it nested within the genus Alaria, sister to $A$. marginata from Pacific Canada in the COI analysis. However, it is noteworthy that the presence of $\beta$-sporophylls with midrib is a stable morphological character in $A$. paradisea, and these structures are absent in other Alaria species. In traditional taxonomy, this unique and stable character was sufficient to separate it as an independent genus, because most alariaceaen genera differ from the genus Alaria only by a single character, same as Pleuropterum (Table 3). There are many laminariaceaen genera established based on a single morphological character, such as the undeveloped blade in Pterygophora, or the absence of sporophylls in Pleurophycus, or septated airfilled midrib in Eualaria (Abbott and Hollenberg 1976, Lee 2008, Klochkova et al. 2009). Some of the characters were verified with molecular data and some are still waiting for the verification. Our field and laboratory observations showed that Alaria species from the northern waters begin reproduction on the second year of life, i.e., by the time they develop sporophylls on the rachis (Klimova and Klochkova 2014, 2017). The earliest observation on the $\beta$-sporophylls appearing in A. paradisea from the Kurile Islands goes back to 1926 with field-collected specimen.

The distribution of A. paradisea in Russian Far East is interesting. There are several reports verified with herbarium samples in early and middle 20th century (Nagai 1940) (Table 1), but recent surveys except ours failed to find this species in its type locality, Atlasov Island, as well as other Kurile Islands. Extensive surveys were performed by researchers from SakhNIRO during 1993-2001 near Atlasov, Shumshu and Paramushir Islands, focusing on the distribution of kelp species, but A. paradisea was not found in those surveys too (Ogorodnikov 2007). Grishin et al. (2009) reported significant changes in the terrestrial flora of Atlasov Island, type locality of A. paradisea, for last several decades and suggested that it may be caused by the recent frequent eruptions of Alaid volcano, which is located in the center of the island. The latest eruption of Alaid volcano occurred in 2012 through 2015. It is not surprising that the underwater volcanic activity can also affect the seaweed distribution in the Kurile Islands, which is surrounded with many active volcanos, thus the underwater eruptions are common. A. paradisea was recently proposed to be included in the Red List of Threatened Species of the Kurile Islands to prevent its harvesting by local and seasonal fishermen (Olga A. Chernyagina personal communication).

The taxonomic revision based on molecular data is still ongoing in many kelp species, especially those, which were established in early and middle 20th century using the materials collected in the expeditions in remoted northern areas. To date, only one out of six endemic kelp species from the Kurile Islands has been confirmed with gene sequencing. Our study highlighted the need for further studies of other laminariaceaen algae from this vast and largely unexplored area of Russian Far East.

\section{ACKNOWLEDGEMENTS}

We are grateful to colleagues who assisted in finding type and other specimens of A. paradisea, including curators of the algal collections of SAP (Dr. Tsuyoshi Abe) and LE (Dr. Tatyana A. Mikhajlova). This study was carried out with the financial support of the Russian Foun-

Table 3. Generic character differences between select alariaceaen taxa ${ }^{\mathrm{a}}$

\begin{tabular}{|c|c|c|c|c|c|c|}
\hline \multirow{2}{*}{ Genus } & \multicolumn{2}{|c|}{ Main blade } & \multicolumn{2}{|c|}{ Midrib on the main blade } & \multicolumn{2}{|c|}{ Sporophylls } \\
\hline & Developed & Undeveloped $^{\mathrm{b}}$ & Simple & Septated $^{\mathrm{c}}$ & Without midrib $(\alpha)$ & With midrib $(\beta)$ \\
\hline Alaria & + & - & + & - & + & - \\
\hline Pleuropterum & + & - & + & - & + & + \\
\hline Eualaria & + & - & - & + & + & - \\
\hline Pleurophycus & + & - & + & - & - & - \\
\hline Pterygophora & - & + & + & - & + & - \\
\hline Undaria & + & - & + & - & $\begin{array}{l}\text { Sporophylls in } 2 \\
\text { discrete pieces }\end{array}$ & - \\
\hline
\end{tabular}

'Data from Miyabe and Nagai (1933), Nagai (1940), Abbott and Hollenberg (1976), Lee (2008), and Klochkova et al. (2009).

${ }^{\mathrm{b}} \mathrm{A}$ number of smooth blades are arranged on either side of the top half of the stipe.

'Divided into compartments. 
dation for Basic Research (RFBR, scientific project No. 16-34-00874 mol_a). This research was also supported by Korea Institute of Planning and Evaluation for Technology in Food, Agriculture, Forestry and Fisheries (IPET) through Golden Seed Project, funded by Ministry of Agriculture, Food and Rural Affairs (MAFRA) (213008-052-SB810) and National Research Foundation of Korea Grant (NRF-2015M1A5A1041804).

\section{REFERENCES}

Abbott, I. A. \& Hollenberg, G. J. 1976. Marine algae of California. Stanford University Press, Redwood City, CA, 827 pp.

Cho, G. Y., Klochkova, N. G., Krupnova, T. N. \& Boo, S. M. 2006. The reclassification of Lessonia laminarioides (Laminariales, Phaeophyceae): Pseudolessonia gen. nov. J. Phycol. 42:1289-1299.

Gollerbah, M. M. 1977. The life of plants. Vol. 3. Prosveszhenie, Moscow, 487 pp. (in Russian).

Grishin, S. Y., Barkalov, V. Y., Verkholat, V. P., Rashidov, V. A., Shlyakhov, S. A. \& Yakovlyeva, A. N. 2009. Vegetation cover and soils of Atlasov Island (the Kurile Islands). Komarov Memorial Lectures LVI:64-119 (in Russian).

Huelsenbeck, J. P. \& Ronquist, F. 2001. MRBAYES: Bayesian inference of phylogenetic trees. Bioinformatics 17:754755.

Klimova, A. V. \& Klochkova, T. A. 2014. Development of gametophytes of laminariacean algae Alaria marginata from the Avacha Bay (southeastern Kamchatka) under laboratory-controlled conditions. Res. Aquat. Biol. Resour. Kamchatka Northwest Part Pac. Ocean 35:48-55 (in Russian).

Klimova, A. V. \& Klochkova, T. A. 2017. Peculiarities of development in the marine brown alga Alaria angusta Kjellman, 1889 (Alariaceae: Ochrophyta) under laboratorycontrolled conditions. Russ. J. Mar. Biol. 43:42-48.

Klochkova, N. G. 1998. An annotated bibliography of marine macroalgae on Northwest coast of the Bering Sea and the Southeast Kamchatka: the first revision of flora. Algae 13:375-418.

Klochkova, N. G. \& Klochkova, T. A. 2010. Costulariella, a new substitute name for Costularia Ju. Petrov et I. Gussarova (Laminariales, Phaeophyceae). Algae 25:183-185.

Klochkova, N. G., Korolyova, T. N. \& Kusidi, A. E. 2009. Atlas of marine algae of Kamchatka and surrounding areas. Vol. 1. Green and Brown algae. KamchatNIRO Press, Petropavlovsk-Kamchatsky, 216 pp. (in Russian).

Klochkova, N. G. \& Krupnova, T. N. 2004. New species of Laminariales (Phaeophyta) from Far East Seas of Russia.
Algologiya 14:86-94.

Klochkova, T. A., Kim, G. H., Belij, M. N. \& Klochkova, N. G. 2012. Morphology and phytogeography of Laminaria appressirhiza and L. inclinatorhiza (Phaeophyceae) from the Sea of Okhotsk. Algae 27:139-153.

Klochkova, T. A., Kim, G. H., Lee, K. M., Choi, H. -G., Belij, M. N. \& Klochkova, N. G. 2010. Brown algae (Phaeophyceae) from Russian Far Eastern seas: re-evaluation of Laminaria multiplicata Petrov et Suchovejeva. Algae 25:77-87.

Klochkova, T. A., Klochkova, N. G., Yotsukura, N. \& Kim, G. H. 2017. Morphological, molecular, and chromosomal identification of dwarf haploid parthenosporophytes of Tauya basicrassa (Phaeophyceae, Laminariales) from the Sea of Okhotsk. Algae 32:15-28.

Lane, C. E., Lindstrom, S. C. \& Saunders, G. W. 2007. A molecular assessment of northeast Pacific Alaria species (Laminariales, Phaeophyceae) with reference to the utility of DNA barcoding. Mol. Phylogenet. Evol. 44:634648.

Lane, C. E., Mayes, C., Druehl, L. D. \& Saunders, G. W. 2006. A multi-gene molecular investigation of the kelp (Laminariales, Phaeophyceae) supports substantial taxonomic re-organization. J. Phycol. 42:493-512.

Lee, Y. 2008. Marine algae of Jeju. Academy Publication, Seoul, 477 pp.

Miyabe, K. \& Nagai, M. 1932. Pleuropterum paradiseum, a new genus and species of Alarieae from the northern Kuriles. Proc. Imp. Acad. 8:127-130.

Miyabe, K. \& Nagai, M. 1933. Laminariaceae of the Kurile Islands. Trans. Sapporo Nat. Hist. Soc. 13:85-102.

Nagai, M. 1940. Marine algae of the Kurile Islands. I. J. Fac. Agric. Hokkaido Imp. Univ. 46:1-137.

National Center for Biotechnology Information (NCBI). 2018. GenBank. Available from: http//www.ncbi.nlm. nih.gov. Accessed Feb 2, 2018.

Ogorodnikov, V. S. 2007. Macroalgae of the northern Kurile Islands. Ph.D. dissertation, KamchatGTU, Petropavlovsk-Kamchatsky, 174 pp. (in Russian).

Petrov, Ju. E. 1975. Laminariacean and Fucacean algae of the USSR's seas. Extended abstract of national doctoral degree dissertation. Leningrad, 53 pp. (in Russian).

Petrov, Ju. E. \& Kusakin, O. G. 1997. Undariella kurilensis a new genus and species of laminariaceous algae for the intertidal zone of Yankich Island (Kurile Islands). Russ. J. Mar. Biol. 23:79-83.

Saunders, G. W. \& Druehl, L. D. 1993. Nucleotide sequences of the internal transcribed spacers and 5.8S rRNA genes from Alaria marginata and Postelsia palmaeformis (Phaeophyta: Laminariales). Mar. Biol. 115:347-352. 
Stamatakis, A. 2014. RAxML version 8: a tool for phylogenetic analysis and post-analysis of large phylogenies. Bioinformatics 30:1312-1313.

Widdowson, T. B. 1964. A study of variation in the genus Alaria Greville. Ph.D. dissertation, University of British Columbia, Vancouver, 229 pp.

Widdowson, T. B. 1971. A taxonomic revision of the genus Alaria Greville. Syesis 4:11-49.
Yamada, Y. 1935. The marine algae of Urup, middle Kuriles, especially from the vicinity of Iema Bay. Sci. Pap. Inst. Algol. Res. Fac. Sci. Hokkaido Imp. Univ. 1:1-26.

Yoon, H. S. \& Boo, S. M. 1999. Phylogeny of Alariaceae (Phaeophyta) with special reference to Undaria based on sequences of the RuBisCo spacer region. Hydrobiologia 398/399:47-55. 